\title{
BURNOUT, ANXIETY AND DEPRESSION AMONG LONG-TERM SICK LEAVE TEACHERS IN TUNISIA: A CASE-CONTROL STUDY

Authors: N. CHARFI ${ }^{1}$, A. BEJAR ${ }^{1}$, S. YAICH ${ }^{2}$, M. MAALEJ BOUALI ${ }^{1}$, S. OMRI ${ }^{1}$, R. FEKI ${ }^{1}$, N. ZOUARI ${ }^{1}$, L. ZOUARI ${ }^{1}$, J. BEN THABET ${ }^{1}$, M. MAALEJ ${ }^{1}$ 1. Hedi Chaker university hospital, psychiatry "C" department, Sfax, Tunisia.

2. Hédi Chaker university hospital, preventive department, Sfax, Tunisia.

\section{Background}

The teachers are exposed to many constraints and pressures related to their work. Individual variables and working conditions can be risk factors for burnout which has important personal and societal repercussions.

\section{Aims}

- Identify the personal and professional factors associated with burnout;

- Determine the links between burnout and anxiety/depression.

\section{Methods}

- A case-control study was conducted between September 2017 and June 2018.

- It included 94 teachers in long-term sick leave, with burnout syndrome assessed with the Burnout Measure Short version and 94 burnout free teachers matched for age and socioeconomic level.

- The Arab version of the Hospital Anxiety and Depression scale (HAD) was used to assess depression and anxiety (cut-off score 11)

\section{Results}

\section{Descriptive part:}

\section{Sociodemographic characteristics:}

\begin{tabular}{|l|l|}
\hline Average age & $48.7 \pm 8.36$ years \\
\hline Sex-ratio & 0.67 (38 men /56 women) \\
\hline $\begin{array}{l}\text { History of somatic } \\
\text { disease(s) } 66 \%\end{array}$ & $\begin{array}{l}\text { high blood pressure: } 19.1 \% \\
\text { diabetes:18.1\% } \\
\text { musculoskeletal diseases: } 29.8 \%, \text { others: } 27.7 \%\end{array}$ \\
\hline Habits & $\begin{array}{l}\text { smoking:26.6\%, alcohol use:9.6\% } \\
\text { sport and/or leisure activity:26.6\% }\end{array}$ \\
\hline
\end{tabular}

\section{Professional characteristics:}

\begin{tabular}{|l|l|}
\hline Teaching establishment & $\begin{array}{l}\text { Primary school:40.4\%, } \\
\text { middle school:26.6\%, high school:31\% }\end{array}$ \\
\hline Seniority at work & $23.96 \pm 9.86$ years \\
\hline $\begin{array}{l}\text { Subject taught } \\
\text { (languages } 60.6 \%)\end{array}$ & $\begin{array}{l}\text { Most common subjects taught were } \\
\text { Arabic (30.9\%), French (19.1\%), English } \\
(10.6 \%)\end{array}$ \\
\hline
\end{tabular}

\section{Anxiety and depression assessment:}

- Average score of anxiety:14.98 ( \pm 3.42$)$

Average score of depression:13.65 $( \pm 3.52)$

- $88.3 \%$ of the teachers with burnout had an anxiety state

and $81.9 \%$ had a depressive state.
Analytical part:

Table 1: Factors correlated to burnout from the comparative study

\begin{tabular}{|l|c|c|}
\hline & $\mathbf{p}$ & OR \\
\hline Somatic diseases & $<0.001$ & 2.1 \\
\hline Smoking & 0.007 & 3.1 \\
\hline Teaching in primary school & $<0.001$ & 1.54 \\
\hline Teaching languages & 0.008 & 1.2 \\
\hline Seniority at work & $<0.001$ & \\
\hline Depression & $<0.001$ & 1.5 \\
\hline Anxiety & $<0.001$ & 3 \\
\hline
\end{tabular}

Discussion

\section{1/ Personal factors affecting burnout:}

* In our study, teachers with somatic diseases were more at risk of burnout $(p<0.001 ; O R=2.1)$, which is in line with the literature.

$\Longrightarrow$ It has been shown that physical illness is more common in burnout and that the prevalence of health problems increases with the severity of this syndrome (1).

The somatic vulnerability seems to be related to the physical symptoms caused by burnout.

* Tobacco smoking correlated with burnout.

$\Longrightarrow$ The unhealthy lifestyle habits can be considered as risk factor for fatigue and affect negatively mental and physical health (2).

\section{2/ Professional factors affecting burnout:}

* Teaching in primary school increased the risk of burnout $(p<0.001)$. $\Longrightarrow$ primary school students seem to be more difficult to interest and teachers need to make more efforts to attract their attention.

* Teaching languages was also associated to burnout:

$\Longrightarrow$ lack of interest of students during these courses comparatively to scientific subjects could explain this result. The lack of motivation of students can accentuate the fatigue of teachers.

* Seniority at work correlated positively with burnout $(p<0.001)$.

$\Longrightarrow$ teachers at the end of their career, who are also the oldest, start to lose professional motivation after many years of hard work (3). In addition, they have poorer physical and psychological health.

3/ Relationship between anxiety, depression and burnout:

Both anxiety and depression correlated with burnout in our study.

In the literature, the relationships between burnout, depression and anxiety remain unclear,

* the symptoms of burnout and the symptoms of depression are quite similar, mostly in the most severe form of burnout (4);

* But they have different etiopathogenesis: burnout is specifically related to someone's working environment (5).

$\Longrightarrow$ Our results suggested the implication of psychiatric morbidity, especially emotional morbidity, in the burnout of teachers.

\section{Conclusion}

The results of our study confirm the existence of relation between burnout and emotional disorders and point up the need of countermeasures at both the organisational and individual level to prevent burnout.

References: (1)Honkonen T, et al. The association between burnout and physical illness in the general populationresults from the Finnish Health 2000 Study. J Psychosom Res. 2006;61(1):59-66.; ;(2)Michal M, et al. Association of mental distress with smoking status in the community J Affect Disord. 2013;146:355-60.; ;(3) Zavidovique L, Gilbert F, VercambreJacquot MN. Bien-être au travall et quallé de vie des enseignants : quelles différences selon l'ancienneté ? Arch Mal Pro Environ. 2018,79(2):105-19. (4) Blanchi R, Boffy C, Hingray C, Truchot D, Laurent E. Comparative symptomatology of burnout

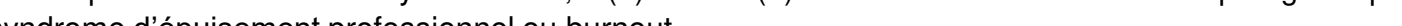

